\title{
Well Differentiated Malignant Neoplasm
}

National Cancer Institute

\section{Source}

National Cancer Institute. Well Differentiated Malignant Neoplasm. NCI Thesaurus. Code C36052.

A neoplasm whose histologic characteristics are similar to the tissue from which it arose. 